Vol. 8, Issue 8, August 2021

DOI: 10.17148/IARJSET.2021.88101

\title{
Finite Element Analysis of Dog Clutch Plate Using Numerical Methods
}

\author{
Suvikram Pradhan ${ }^{1}$, Bibhuti Biswal ${ }^{2}$,G. Avinash Sharma ${ }^{3}$, Anshuman Nayak ${ }^{4}$, Hritik Ranjan Behera ${ }^{5}$ \\ UG - Mechanical Engineering, GIET University, Gunupur, Odisha, India ${ }^{1,2,3,4,5}$
}

\begin{abstract}
Due to the advancement of technologies all the automotive industries have advanced further and all the automotive instruments has been changed but all the components related to the power train are still intact and all are being used. And one of the major components is the clutch that is being used to transmit the power from the main engine shaft to the gear box and it will be further transferred and helps the vehicle to run. In this research work all the forces and the stress acting on the clutch along with motion of the vehicle is being so that it wouldn't fail under the normal circumstances and all the above tasks are being carried out using CAD and CAM software's named CATIA used for designing of model and ANSYS for the simulation of the CAD model.
\end{abstract}

Keywords: CATIA, ANSYS, CAD, CLUTCH, FEM

INTRODUCTION:

Clutch can be defined as the mechanical device which is used for transmission of power from the box shaft main engine shaft to the gear box shaft. Clutch has to perform various operations and the main characteristics of a clutch are:

1) Good wear and tear characteristics.

2) Cost Effective.

3) Corrosion Resistant.

4) Withstand high temperatures.

The main functions of the clutch are:

1) Gradual engagement and disengagement.

2) Heat Dissipation.

3) Ease of operation.

4) Transmit power without slipping.

5) Noiseless operation.

6) Transmission of torque.

Types:

1) Cone clutch

2) Plate clutch

i. Single plate

ii. Multi Plate

3) Friction clutch

4) Dog clutch

5) Fluid clutch

6) Centrifugal clutch

Since there is advancement in the automobile sector torque converters are used for transmission of power instead of clutch and the major components of the torque converter are (Basically these torque converters are a type of fluid coupling that is capable of generating some amount of torque):

1) Flywheel

2) Impellor

3) Stator

4) Turbine

5) Gearbox

In this research paper a single plate clutch is being considered and being analyzed for the calculation of various stresses that is being acting on the clutch.

The figure shown below shows the various types of clutch: FIGURE 1.1 
DOI: 10.17148/IARJSET.2021.88101

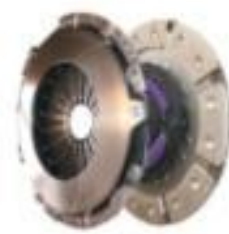

Friction clutch

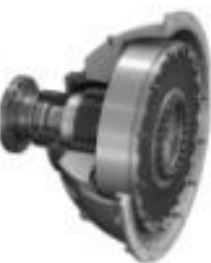

Cone clutch

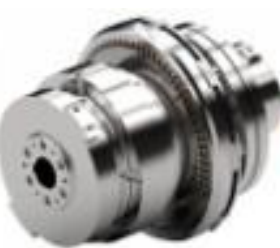

Safety clutch

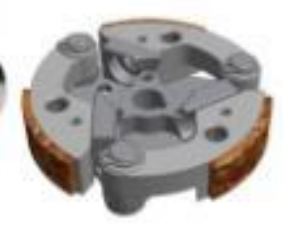

Centrifugal clutch Electromagnetic clutch

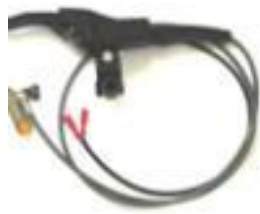

Hydraulic clutch

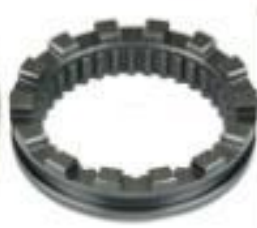

Dog clutch

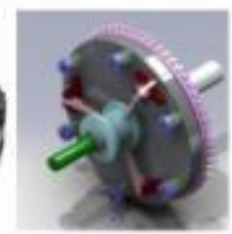

Single plate clutch

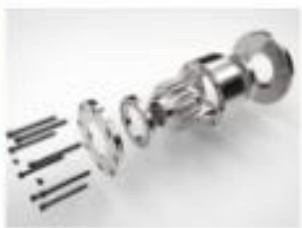

Overrunning clutch
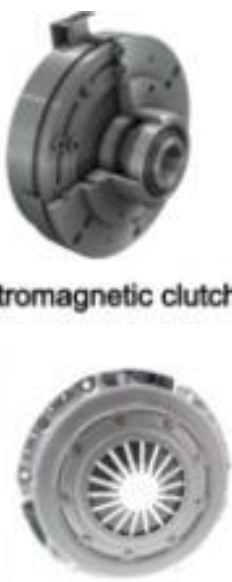

Diaphragm clutch

The figure shown below shows the various parts of power train of an automobile: FIGURE 1.2

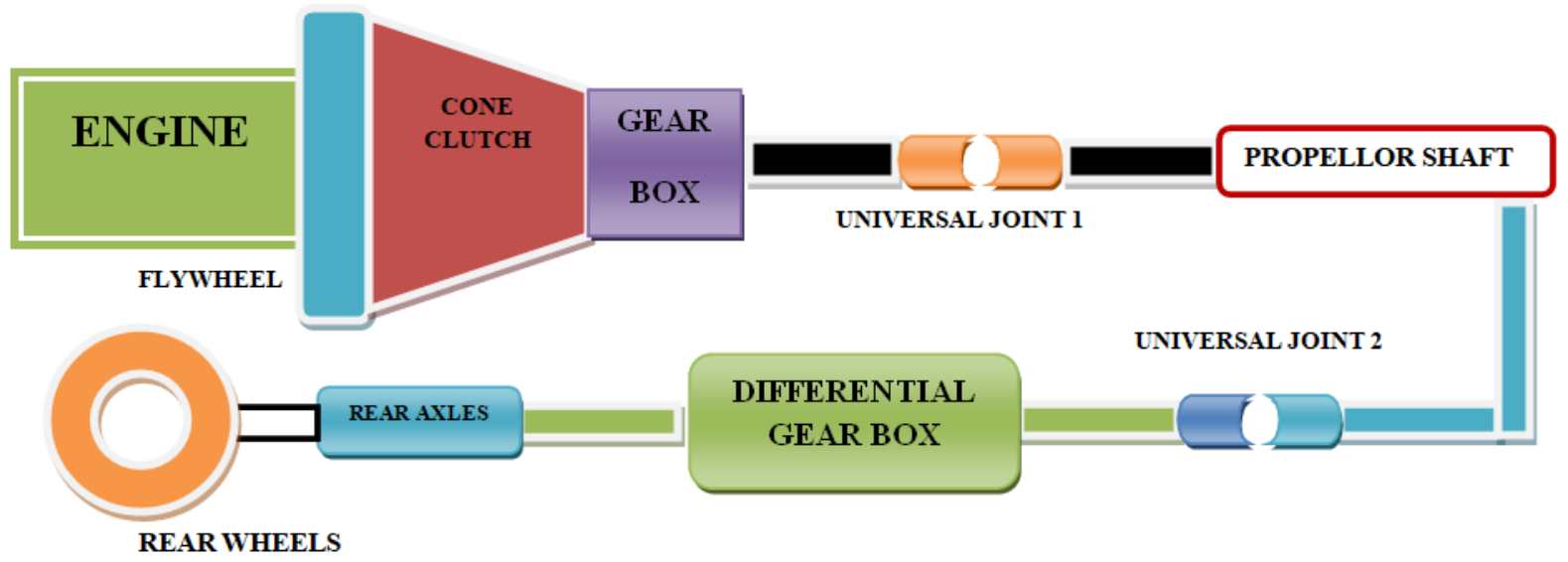

\section{OBJECTIVES:}

1) Design of clutch using CATIA.

2) Analysis of clutch using ANSYS.

\section{LITERATURE REVIEW:}

\section{1) DESIGN AND FINITE ELEMENT ANALYSIS OF AN AUTOMOTIVE CLUTCH ASSEMBLY,BY RAJESH PUROHIT,POOJA KHITOLIYA,DINESH KUMAR KOLI,ON 2014}

Here, in this paper it has been clearly mentioned about the FEA(FINITE ELEMENT ANALYSIS) which is being used in a more wide basis and is even widely accepted computational tool that is used for an engineering analysis .As the clutch's purpose is for initiating the motion or for increasing the velocity of a body as well as for transfer of kinetic energy from the moving body. This paper also deals with the designing of the frictional clutch assembly .Using the ANSYS software the static structural analysis was performed .The material assignment are as followed : clutch platestructural steel, pressure plate-cast iron GS-70-02 and diaphragm spring-spring steel are preferred. The friction material that is assumed is molded asbestos for opposing cast-iron/steel surface .In this paper it is also mentioned about the solid modeling bring done for the description offered for the sufficient geometric data in order for the construction of mesh in the finite element modeling purpose .PUROHIT and SAGAR (2005-2006)have performed about the finite element analysis of the AI-SICP composite poppet valve guides and the valve seal inserts.PUROHIT.et.al.(2010) have performed on the topic of the linear static-analysis of the piston in the motor cycle. GOA LION-HUA,JIA XIAOPING(1993) reported the results drawn from the experiment in which it was found about the main clutch of heavy vehicles which is basically the execution component, which helps realizing about the vehicle to start, shift, move as well as stop. The observation made was done in order for prevention of the transmission device as well as the engine from being damaged by the too heavy load during the excessive change of the load. In the present work a clutch 


\section{DOI: 10.17148/IARJSET.2021.88101}

assembly is during designed through the solid works office premium software. The assembly consisted of the clutch plate, pressure plate and a diaphragm spring.

\section{2) DESIGN AND ANALYSIS OF CLUTCH PLATE USING STEEL MATERIAL-HISANAO KITABAYASHI, CHEN YU LI AND HENERY HIRAKI}

Here, the experiments under which the mentioned about the effect of design factors of clutch packs on the drag torque. The design factor being used with large effects used various facing area as well as the wave height. At the low rotational speeds, since the drag torque increased in a linear manner with the increasing speed. The results were then compared with the help of the theoretical equations and the theoretical valve. NEWTON'S law of viscosity was the main equation on which the theoretical values were based. The ATF (AUTOMATIC TRANSMISSION FLUID) flow on the rotating facing surface which the ATF covered completely at lower rotational speed with the mixture of high rotational speeds. KAVLICOGLU, BAUKAN $\mathrm{M}$ and GORDANINJAD focused upon the design as well as characterization of the radial double plate magnet rheological fluid (MRF) clutch by applying the magnetic field the torque output applied can be controlled. The (FEA) is performed such that for designing as well as optimizing the clutch. The shear stress distribution in MRF in between the plants is predicted by the magnetic flux density theoretically the output valve of torque was recorded through different input valves of velocities as well as the magnetic fields been applied. The clutch is also capable of demonstrating a high amount of controllable torques. RAJESH PUROHIT also dealt with the friction clutches assembly and did it by the help of ANSYS software. Uniform wear theory was used for the ANSYS purpose for clutch plate-structural steel, pressure plate-cast iron GS-70-02 as well as diaphragm spring-spring steel.

\section{3) DESIGN AND STRUCTURAL ANALYSIS OF SINGLE PLATE FRICTION CLUTCH,BY MR. VISHAL J.DESHBHRATOR,MR.NAGPATH U.KAKDE ON 10 OCTOBER 2013}

Here it is clearly mentioned about the design of the friction clutches of the automobiles, as well as the thermo elasticity of a priori is very much informative in such phases of initial design. The precise decision technique of the various maximum structural stresses must be requested for the designing of the mechanical clutches because of their durability and compactness. Here in this paper various study and research work will done for an efficient as well as reliable analysis technique for the design of mechanical clutches by the use of various computer modeling and numerical method which is being developed. Clutch is basically a device used for the transmission system of a vehicle for engaging and the disengaging of the transmission system for the engine. When the clutch is engaged, the plates as well as the facings rotate with respect to the hub to limit of the torsion springs or to limit of the spring which then stops. Clutch plate in case of cars get controlled in case of the left most pedal. It engages and then disengages once the clutch plates are engaged. One can get the clutch plate engaged by appliance of no pressure on the lever. The structural analysis can be done by the help of various linear as well as non linear models. Linear models included simple parameter and the assumption of materials which is not deformed plastically. Non linear models consisted of the various stresses on material past the elastic capabilities. It included various analytical methods, strength of materials methods and finite element methods. After the completion of analysis in CAD software i.e. ANSYS 9.0 the values of various equivalent stresses for the material loading conditions which is seen clearly which are less than the allowable stresses for particular material.

\section{4) STRESS AND THERMAL ANALYSIS OF CLUTCH PLATE, BY UDIT SINGHAL, RAKSHIT KUMAR AND GHOGARE SUBNAM SHURSEN, BASKAR P, ON MARCH 2018}

Here it is clearly mentioned about clutch which is one of the main components in automobile. The clutch helps in transmitting the engine power to the system. The Finite Element Analysis(FEA) are basically accurate and hence is used worldwide for various design and research engine and research engineers. An efficient as well as reliable analysis technique is used for design of the mechanical clutch plates and for this ANSYS 16.0 is used and mathematical calculations are often used for the analysis purpose. It contained various stress and thermal analysis of the three different design variants for the single plate clutch plate friction of the automobile which is the Tata Super Ace. The modeling was done in solid works software and the analysis was been done in the ANSYS software and results of variants were compared. Various parts of single plate clutch are been referred in this paper. The clutch is used most commonly. The flywheel is being installed in the crankshaft as well as rotates with it. Then Pressure plate is installed in the flywheel with the help of the clutch springs. Then the clutch pedal is then pressed affecting the axial movement of pressure plate. The spring action helps in serving in order to reduce the tensile vibrations as well as the shocks in between the engine and transmission during the case of clutch operation. A friction lining is present in the clutch plate for allowing the transmission of torque. The flywheel then starts to spin immediately when the engine is been turned on and the crankshaft is being turned by the motor. The results occurred are very much favourable to what was expected. 
MATERIAL SELECTION:

The materials that are being used for the manufacturing of the automotive parts are required to have the following characteristics:

1) Corrosion Resistance

2) Less cost

3) Economic

4) Anti fade characteristics

5) Good quality

6) Conformation to standards

Most common materials that are being used for the manufacturing of the clutch are described below:

1) Ceramics

2) Copper

3) Stainless Steel

4) Cast Iron

5) Composite materials

Table 1: - Chemical Composition of Stainless Steel

\begin{tabular}{|cc|}
\hline Elements & Composition \\
\hline Carbon, $\mathrm{C}$ & $0.25-0.290$ \\
\hline Copper,Cu & 0.20 \\
\hline Iron,Fe & 98.0 \\
\hline Manganese,Mn & 1.03 \\
\hline Phosphorous,P & 0.040 \\
\hline Silicon,Si & 0.280 \\
\hline Sulphur,S & 0.050 \\
\hline
\end{tabular}

Table 2: - Chemical Composition of Grey Cast Iron

\begin{tabular}{|cc|}
\hline Elements & Composition \\
\hline Carbon,C & 3.35 \\
\hline Silicon,Si & 2.21 \\
\hline Manganese,Mn & 0.34 \\
\hline Phosphorous,P & 0.15 \\
\hline Sulphur,S & 0.091 \\
\hline Selenium Se & 1.01 \\
\hline $\mathbf{T}_{\text {odl }}{ }^{\mathbf{c}}$ & 1330 \\
\hline
\end{tabular}

\section{DESIGN PARAMETERS:}

The design of the flywheel is done using CATIA modeling software.

\section{SOFTWARES USED:}

CATIA stands for Computer-Aided Three-dimensional Interactive Application. Which was developed by a French company named Dassault System. Initially, it was named CATI (conception assistéetridimensionnelle interactive French for interactive aided three-dimensional design) which later changed to CATIA. The first version v1 was released in 1981 and the popular version v5 was released in 2001 which is still in use. CATIA is not only a CAD (ComputerAided Design) software but also a package that supports CAE (Computer-Aided Engineering), CAM (Computer-Aided Manufacturing), and PLM (Product Lifecycle Management) which is largely used in the engineering field particularly in aerospace and automobile industries. The companies that are using CATIA are Boeing, Airbus, Porsche, Audi, Volkswagen, Tata Motors, Mahindra \& Mahindra Limited, etc.

ANSYS Mechanical software is a comprehensive FEA analysis (finite element) tool for structural analysis, including linear, nonlinear, and dynamic studies. The engineering simulation product provides a complete set of elements behavior, material models, and equation solvers for a wide range of mechanical design problems. In addition, ANSYS Mechanical offers thermal analysis and coupled-physics capabilities involving acoustic, piezoelectric, thermalstructural, and thermo-electric analysis. 
International Advanced Research Journal in Science, Engineering and Technology

Vol. 8, Issue 8, August 2021

DOI: 10.17148/IARJSET.2021.88101

DESIGN:FIGURE SHOWING CAD MODEL IN CATIA WORKBENCH:
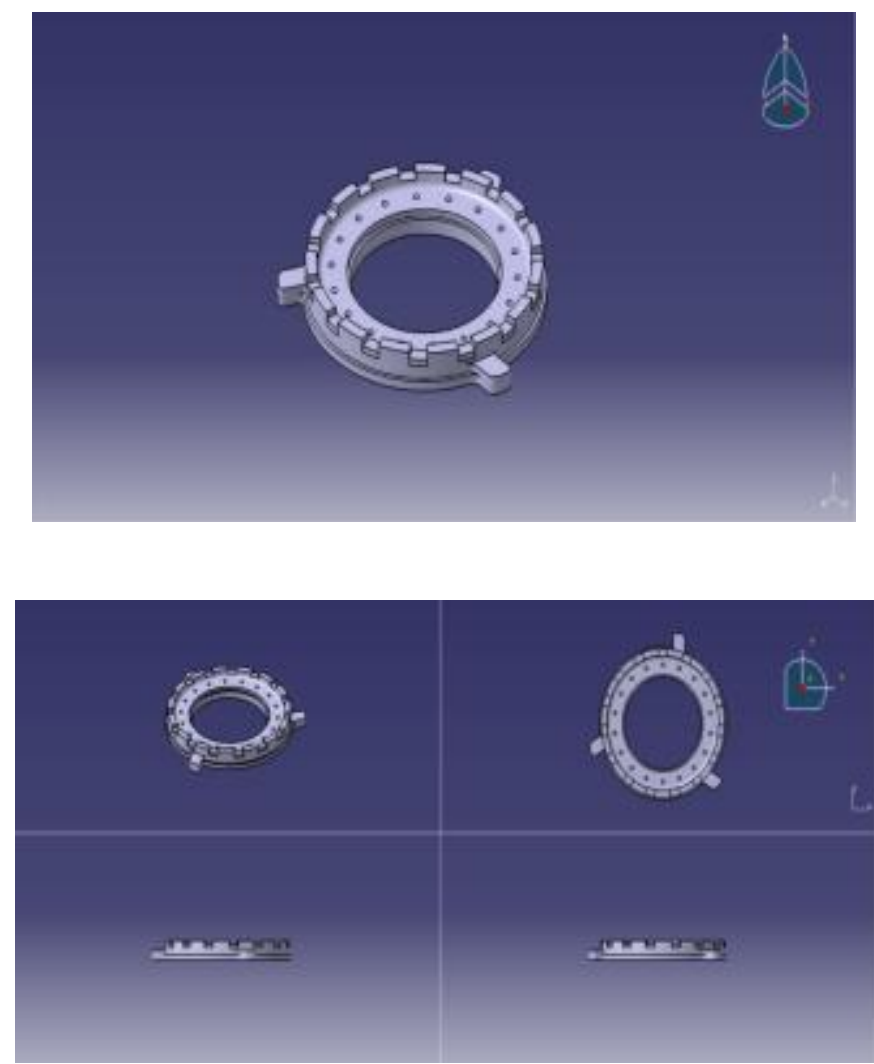

FIGURE SHOWING CAD MODEL IN ANSYS WORKBENCH:

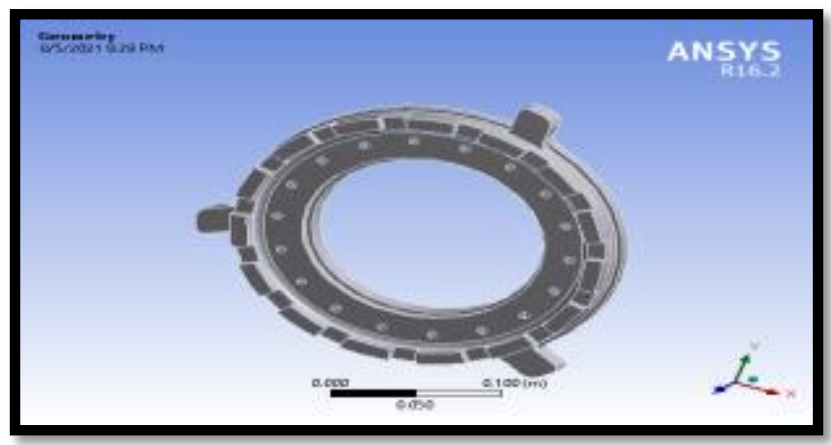

FIGURE SHOWING CAD MODEL IN CATIA WORKBENCH DRAFTING: 
International Advanced Research Journal in Science, Engineering and Technology

Vol. 8, Issue 8, August 2021

DOI: 10.17148/IARJSET.2021.88101

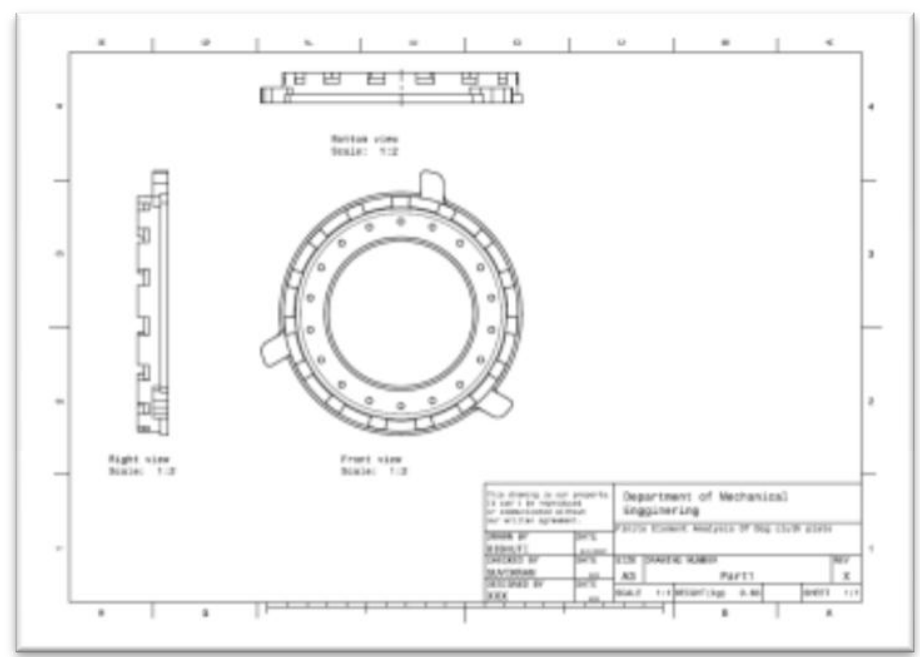

ANALYSIS:

The analysis of the clutch is done using one of the numerical computational techniques known as FEM \{FINITE ELEMENT ANALYSIS \}. Here the whole cad model is divided into small fragments by meshing and overall simulation analysis is carried out using "ANSYS MECHANICAL”.

\section{MESHING:}

It is one of the steps in the FEM in which several nodes and parts are created and the following information was obtained:

No of Nodes $=25907$

No of Elements $=15545$

FIGURE SHOWN AFTER MESHING:

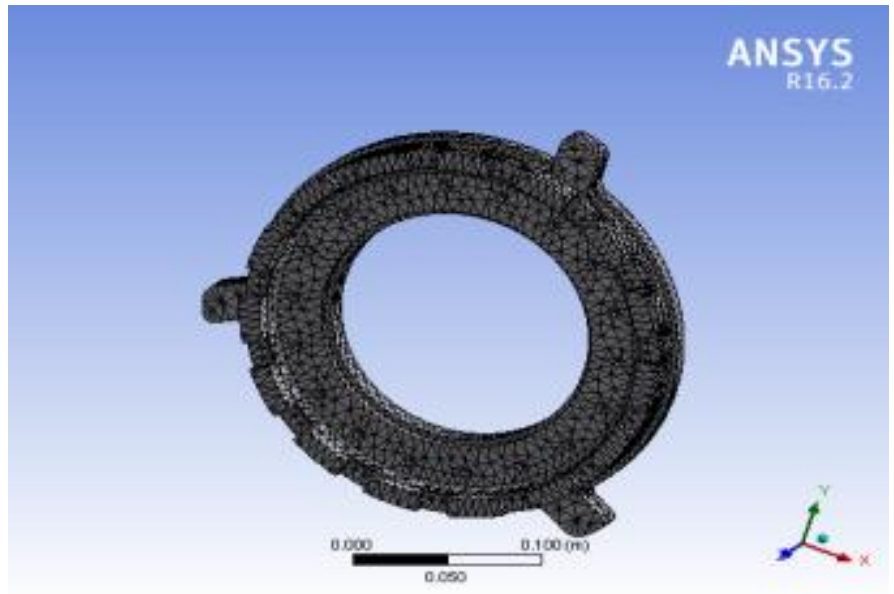


International Advanced Research Journal in Science, Engineering and Technology

Vol. 8, Issue 8, August 2021

DOI: $10.17148 /$ IARJSET.2021.88101

\section{CAE ANALYSIS \{STATIC STRUCTURAL\} OF THE DESIRED CLUTCH:}

\section{1) STRUCTURAL STEEL}
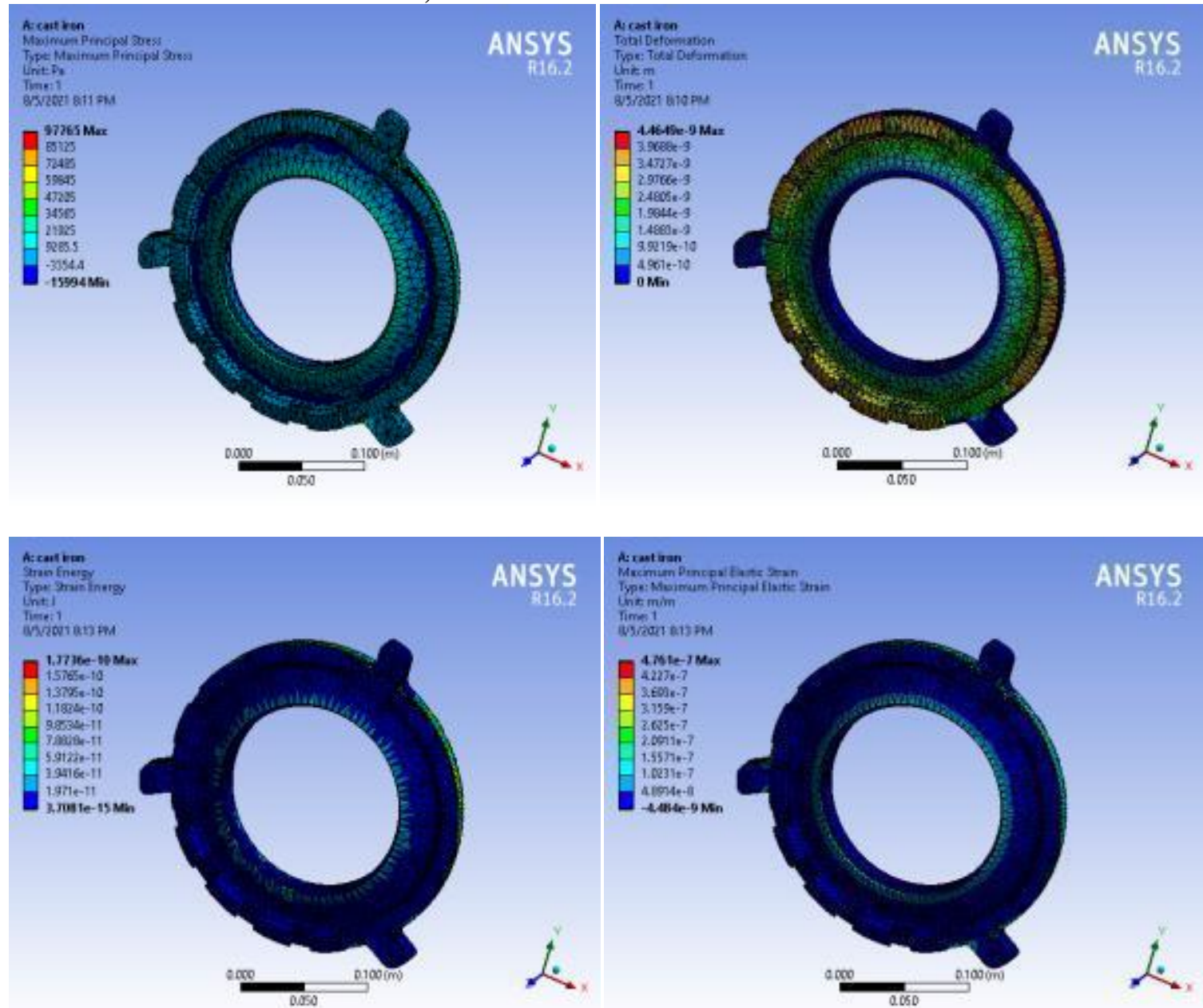

2) CAST IRON
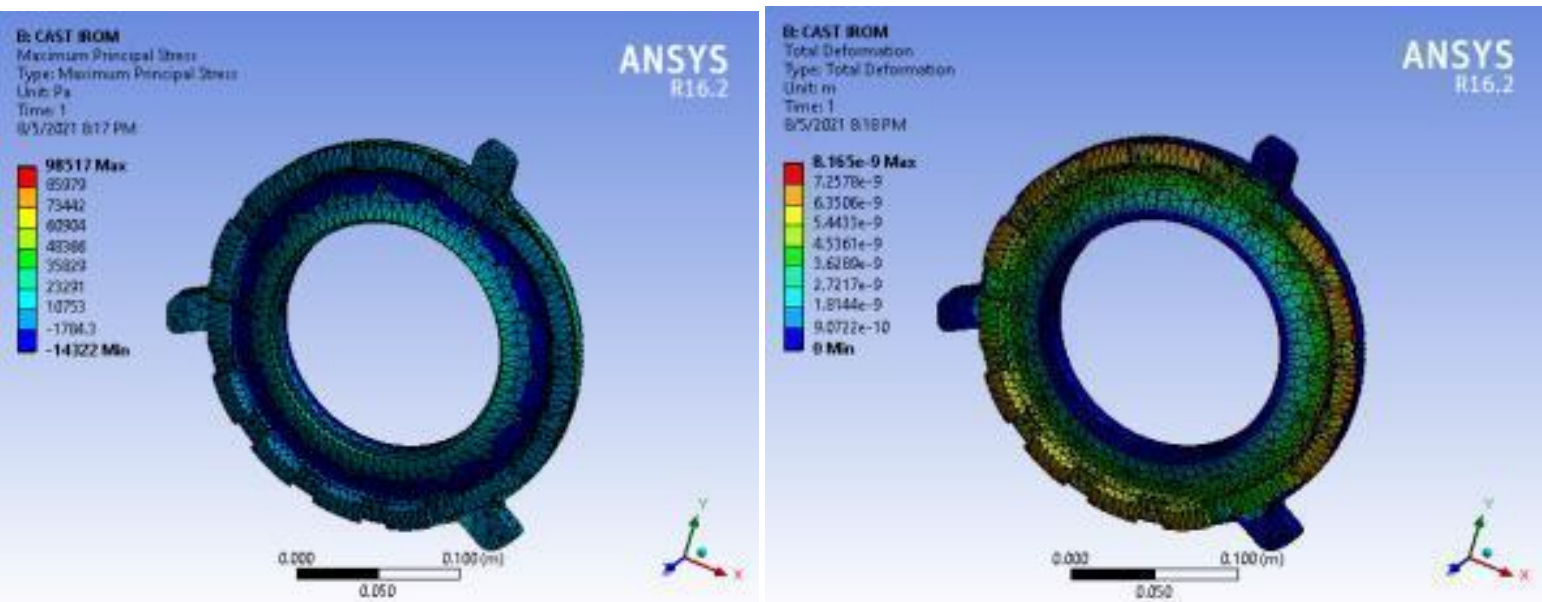
International Advanced Research Journal in Science, Engineering and Technology

Vol. 8, Issue 8, August 2021

DOI: 10.17148/IARJSET.2021.88101
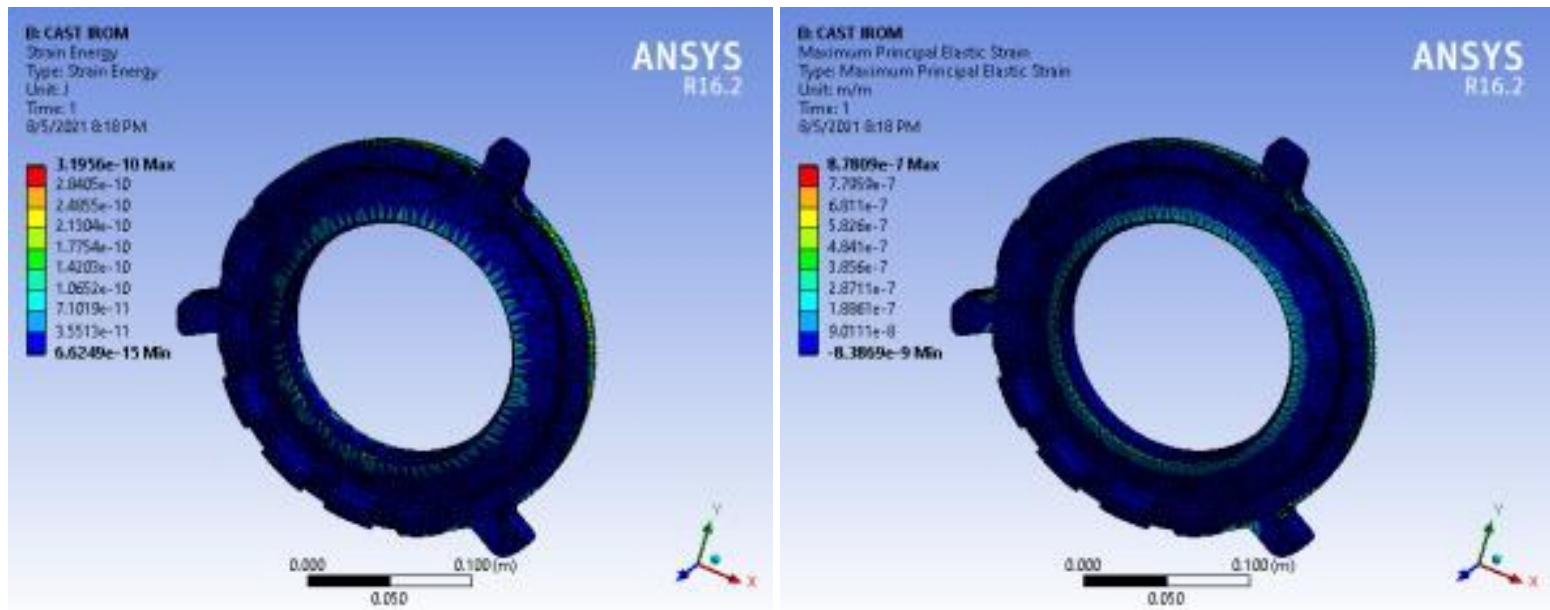

3) STAINLESS STEEL

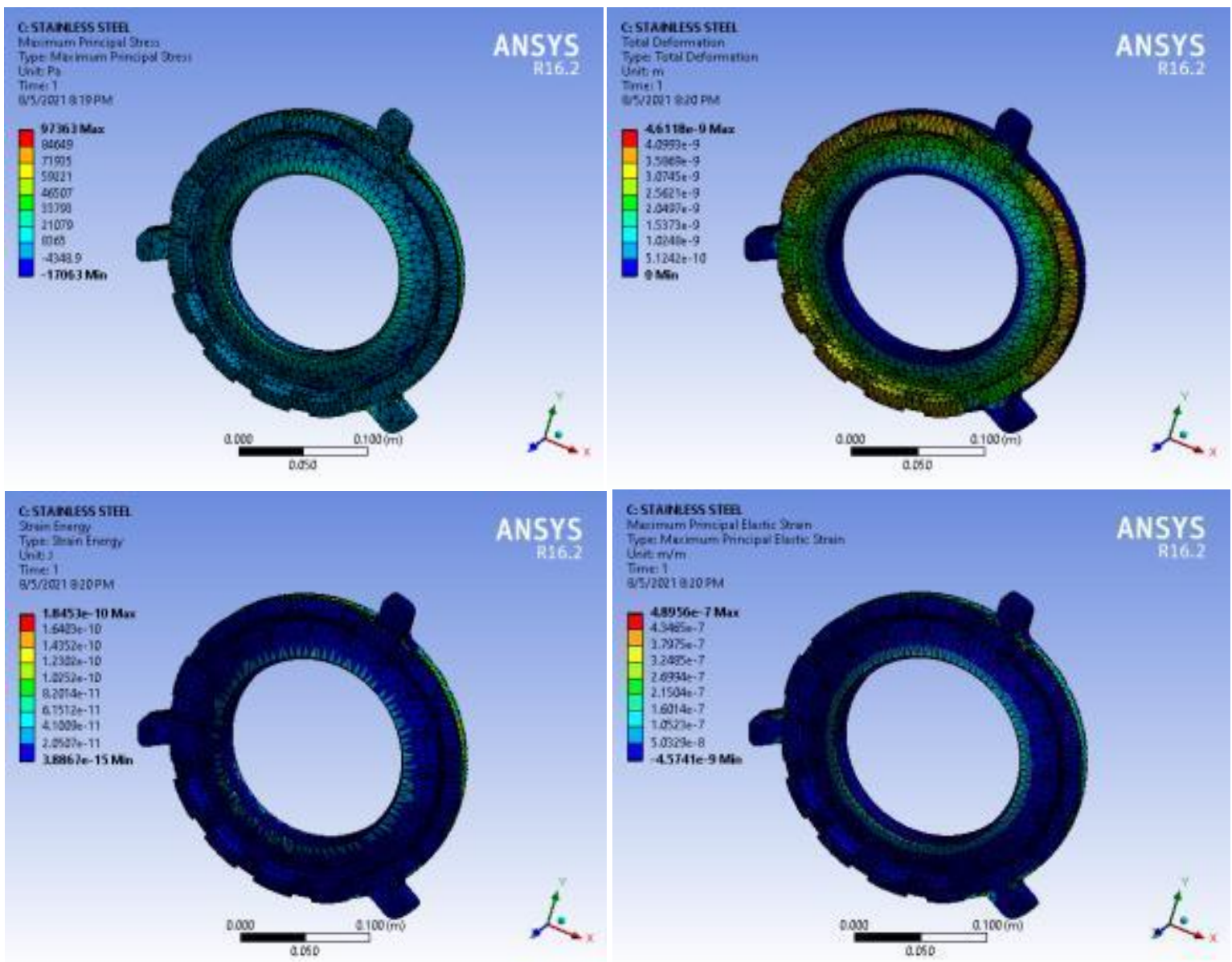


4) COPPER
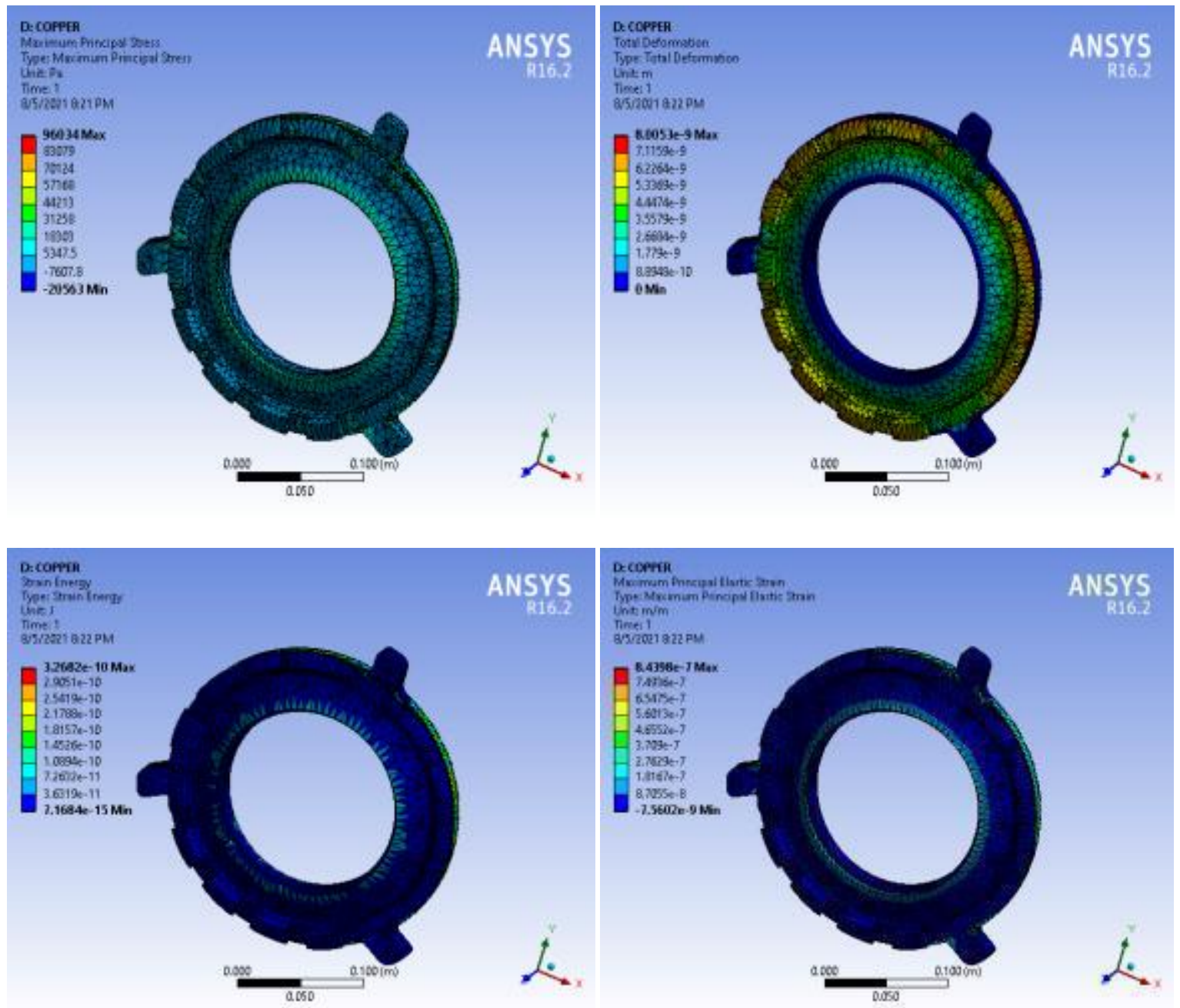

RESULTS AND RESULT TABULATION:

From the above experiments, we have formulated the CAD model of the DOG CLUTCH that is used in almost all the internal combustion engines or engine powered vehicles and have done the analysis of it using ANSYS software and got various results and those are TABULATED below:

\begin{tabular}{|c|c|c|c|c|c|c|}
\hline S.NO & SI UNITS & PARAMETER & & CAST IRON & COPPER & $\begin{array}{l}\text { STAINLESS } \\
\text { STEEL }\end{array}$ \\
\hline \multirow[t]{2}{*}{1.} & $\mathbf{m}$ & \multirow{2}{*}{$\begin{array}{l}\text { Total } \\
\text { Deformation }\end{array}$} & $\min$ & \multirow{2}{*}{$\begin{array}{l}\text { 0 } \\
8.165 \mathrm{e}-9\end{array}$} & \multirow{2}{*}{$\begin{array}{l}0 \\
8.0053-9\end{array}$} & \multirow{2}{*}{$\begin{array}{l}0 \\
4.6118 \mathrm{e}-9\end{array}$} \\
\hline & $\mathbf{m}$ & & $\max$ & & & \\
\hline \multirow[t]{2}{*}{2.} & $\mathbf{m} / \mathbf{m}$ & \multirow[t]{2}{*}{ Strain } & $\min$ & \multirow{2}{*}{$\begin{array}{l}8.3869 \mathrm{e}-9 \\
8.7809 \mathrm{e}-7\end{array}$} & \multirow{2}{*}{$\begin{array}{l}-7.5602 \mathrm{e}-9 \\
8.4398 \mathrm{e}-7\end{array}$} & \multirow{2}{*}{$\begin{array}{l}-4.5741 \mathrm{e}- \\
4.8956 \mathrm{e}-7\end{array}$} \\
\hline & $\mathbf{m} / \mathbf{m}$ & & $\max$ & & & \\
\hline \multirow[t]{2}{*}{3.} & $\mathbf{P a}$ & \multirow[t]{2}{*}{ Stress } & $\min$ & \multirow{2}{*}{$\begin{array}{l}-14322 \\
98517 \\
\end{array}$} & \multirow{2}{*}{\begin{tabular}{|l|}
-20563 \\
96034 \\
\end{tabular}} & \multirow{2}{*}{$\begin{array}{l}-17063 \\
97363 \\
\end{array}$} \\
\hline & $\mathbf{P a}$ & & $\max$ & & & \\
\hline \multirow[t]{2}{*}{4.} & $\mathbf{J}$ & \multirow[t]{2}{*}{ Strain Energy } & $\min$ & \multirow{2}{*}{$\begin{array}{l}6.6249 \mathrm{e}-15 \\
3.1956 \mathrm{e}-10\end{array}$} & \multirow{2}{*}{$\begin{array}{l}7.1684 \mathrm{e}-15 \\
3.2682 \mathrm{e}-10\end{array}$} & \multirow{2}{*}{$\begin{array}{l}3.8867 e-15 \\
1.8453 e-10\end{array}$} \\
\hline & $\mathbf{J}$ & & $\max$ & & & \\
\hline
\end{tabular}

\section{CONCLUSION:}

From the above research it can be concluded that the materials that are being used for the manufacturing of all the automobile components should have some desired characteristics as discussed above. So the most common materials for clutch includes cast iron, steel, composites and the ceramics and these are not limited to these only.From the 


\section{International Advanced Research Journal in Science, Engineering and Technology}

Vol. 8, Issue 8, August 2021

\section{DOI: 10.17148/IARJSET.2021.88101}

numerical analysis we can conclude that stainless steel is more effective for its usage for the manufacturing of clutch as compared to the other materials.

\section{ACKNOWLEDGMENT:}

The authors would like to thank all the persons who are involved and helped in the completion of the above research and the enthusiasm and willingness to learn about the systems discussed above kept the work on track and its completed in some sort of time.

\section{REFERENCES:}

1. Rajesh Purohit, Pooja Khitoliya, Dinesh Kumar Koli, "Design and Finite Element analysis of an Automotive Clutch Assembly", $3^{\text {rd }}$ international conference on material properties and characterization (IMPC 2014).

2. Pappuri Hazarathaiah, Y Ashok Kumar Reddy, "Design and Analysis of Clutch Plate Using Steel Material", IJREAM , Vol-04, Issue-11, Feb 2019

3. Mr. Vishal J. Deshbhartar, Mr. Nagnath U. Kakde, "Design and Structural Analysis of Single Plate Friction Clutch", IJERT, Vol-02, Issue-10, Oct 2013

4. Udit Singhal, Rakshit Kumar, Ghogare Subham Shursen, Bhaskar p, "STRESS AND THERMAL ANALYSIS OF CLUTCH PLATE", IJMET, Vol-09, Issue-03, March 2018

5. $\quad$ Crandall S H, "Engineering Analysis", Mc Graw-Hill, New York,1956

6. G. Shaanit, S.Praveen Kumar, "Finite Element Analysis on Friction Plate Of a Wet Multiple Clutch by Using Various Friction Materials", IRJET, Aug 2017

7. Cm. Prabhujyothi ,Mg Mahesh, "Design and Analysis of Multiplate Clutch by ANSYS", AIJERAS, Feb 2017

8. Zhuo Chen, "Finite Element Analysis of Thermomechanical Processes in Disk Clutch Systems", A Thesis Presented to the Faculty of Engineering and Computer Science University of Denver, March 2013

9. Timoshenko S., "Element of Strength of Materials", Part I and II, Van Nastrond, New Jersey, 1956

10. Lu, Z., Chen, H., Wang, L., \& Tian, G. (2017). The engaging process model of sleeve and teeth ring with a precise, continuous and nonlinear damping impact model in mechanical transmissions (No. 2017-01-2443). SAE Technical Paper.

11. Bóka, G., Márialigeti, J., Lovas, L., \&Trencséni, B. (2010). Face dog clutch engagement at low mismatch speed. PeriodicaPolytechnica Transportation Engineering, 38(1), 29-35.

12. Jeong, S. H., \& Kim, K. S. (2018). A 2-speed small transmission mechanism based on twisted string actuation and a dog clutch. IEEE Robotics and Automation Letters, 3(3), 1338-1345.

13. Shiotsu, I., Tani, H., Kimura, M., Nozawa, Y., Honda, A., Tabuchi, M., ... \&Kanzaki, K. (2019). Development of High Efficiency Dog Clutch with One-Way Mechanism for Stepped Automatic Transmissions. International Journal of Automotive Engineering, 10(2), 156-161.

14. Lu, Z., Tian, G., \&Onori, S. (2020). Time-Optimal Coordination Control for the Gear-Shifting Process in Electric-Driven Mechanical Transmission (Dog Clutch) Without Impacts. SAE International Journal of Electrified Vehicles, 9(14-09-02-0010).

15. Achtenova, G., Jasny, M., \&Pakosta, J. (2018). Dog Clutch Without Circular Backlash (No. 2018-01-1299). SAE Technical Paper.

16. Mizuno, K., Hamaoka, S., Kittaka, E., \& Kobayashi, M. (2009). Development of a Dual-Clutch Transmission System for ATVs (No. 2009-01-0514). SAE Technical Paper.

17. Sun, S., Gong, M., Wu, B., \& Zou, Y. (2020, July). Research on optimal meshing speed difference based on shift success probability for dog Clutch in automated manual transmission. In IOP Conference Series: Materials Science and Engineering (Vol. 892, No. 1, p. 012052). IOP Publishing.

18. Bóka, G., Lovas, L., Márialigeti, J., \&Trencséni, B. (2010). Engagement capability of face-dog clutches on heavy duty automated mechanical transmissions with transmission brake. Proceedings of the Institution of Mechanical Engineers, Part D: Journal of Automobile Engineering, 224(9), 1125-1139.

19. Achtenová, G., Pakosta, J., \& El Morsy, M. SMOOTHNESS OF MAYBACH DOG CLUTCH SHIFT IN THE AUTOMOTIVE GEARBOX.

20. Jasný, M., Hajžman, M., \&Achtenová, G. (2019). Multi-body simulation of dog clutch engagement.

21. Camilleri, R., Armstrong, P., Ewin, N., Richardson, R., Howey, D. A., \& McCulloch, M. D. (2013). The value of a clutch mechanism in electric vehicles. World Electric Vehicle Journal, 6(3), 696-706.

22. Kern, M., Wunder, M., \&Stifter, C. (2014). Multi-speed Transmission with Dog Clutch for Hybrid Drives. ATZ worldwide, 116(5), 28-

23. Kern, M., Wunder, M., \&Stifter, C. (2014). Multi-speed Transmission with Dog Clutch for Hybrid Drives. ATZ worldwide, 116(5), 28-

31.

24. Zhai, Y., Dong, G., Jiang, Z., Liang, Q., Li, X., \& Wang, F. (2020, December). Cooperative Motor Control for Dog Clutch Engagement of Electric Vehicles Based on Smith Predictor. In 2020 4th CAA International Conference on Vehicular Control and Intelligence (CVCI) (pp. 221-225). IEEE.

25. Andersson, M., \& Goetz, K. (2010). FE analysis of a dog clutch for trucks withall-wheel-drive.

26. Guangcai, T., Bo, G., \&Jumin, J. (2011). Strength Verification of the Dog Clutch for the Differential Lock of an Off-road Vehicle. Mechanical Science and Technology for Aerospace Engineering, 04.

27. Fredriksson, J., \&Egardt, B. (2000, December). Nonlinear control applied to gearshifting in automated manual transmissions. In Proceedings of the 39th IEEE Conference on Decision and Control (Cat. No. 00CH37187) (Vol. 1, pp. 444-449). IEEE.

28. Yue, H., Zhu, C., \& Gao, B. (2018). Fork-less two-speed I-AMT with overrunning clutch for light electric vehicle. Mechanism and Machine Theory, 130, 157-169.

29. Gaertner, L., \&Ebenhoch, M. (2013). The ZF automatic transmission 9HP48 transmission system, design and mechanical parts. SAE International Journal of Passenger Cars-Mechanical Systems, 6(2013-01-1276).

30. Reddy J N ," An Introduction to the finite element Method", Mc Graw Hill Book Co, Singapore, International student edition, 1985

31. Desai C S and J F Wilson, "Numerical method in FEA", Prentice-Hall of India Private limited, New Delhi, 1978

32. ChandramouliHarige Ramaswamy; Chakradhar Goud. "Stress Intensity factors of a semi-elliptical crack in a Compressor blade of dovetail joint through numerical approach". International Research Journal on Advanced Science Hub, 3, 4, 2021, 61-66. doi: 10.47392/irjash.2021.115. 


\section{International Advanced Research Journal in Science, Engineering and Technology}

Vol. 8, Issue 8, August 2021

\section{DOI: 10.17148/IARJSET.2021.88101}

33. Rupa Athimakula; Lakshmi Kanth; Sai BargavChowdary B; Ismail Kakarwada. "Modeling and Analysis of Cylinder Block for V8 Engine". International Research Journal on Advanced Science Hub, 2, 12, 2020, 30-40. doi: 10.47392/irjash.2020.245

34. Senbhaga Priya S; Sathya S. "Experimental Analysis of Cold Formed Steel Purlin and Comparison of C and Z Section Using Ansys". International Research Journal on Advanced Science Hub, 2, 7, 2020, 24-28. doi: 10.47392/irjash.2020.59

35. Trang G and B J F ix, An Analysis of the finite element method, prentice Hall, Englewood cliffs, N.J,1973

36. "Structural and Thermal Analysis of a Single Plate Dry Friction Clutch Using Finite Element Method (Fem)" IDL - International Digital Library of Technology \& Research Volume 1, (Issue 5), May 2017

37. J. S. Brar, R. K. Bansal, "Theory of Machines" Page 253-255

38. R. Purohit, P. Khitoliya, and D. K. Koli, "Design and finite element analysis of an automotive clutch assembly," Procedia materials science, vol. 6, 2014

39. R. Purohit and R. Sagar, "Finite-element analysis of al-sicp composite poppet valve guides," tech. rep., SAE Technical Paper, 2005

40. G. Lian-hua and J. Xiao-Ping, "The structure of a tankem," 1993

41. Mattias Andersson, Kordian Goetz, "FE analysis of a dog clutch for trucks with all-wheel-drive", Linnaeus University School of Engineering, 2010

42. Dr. Kripal Singh "Automobile Engineering " Vol i and ii

43. Chengwu Duan,General Motors Co, "Analytical Study of a Dog Clutch in Automatic Transmission Application", SAE International Journal of Passenger Cars, may 2014

\section{AUTHORS BIOGRAPHY:}

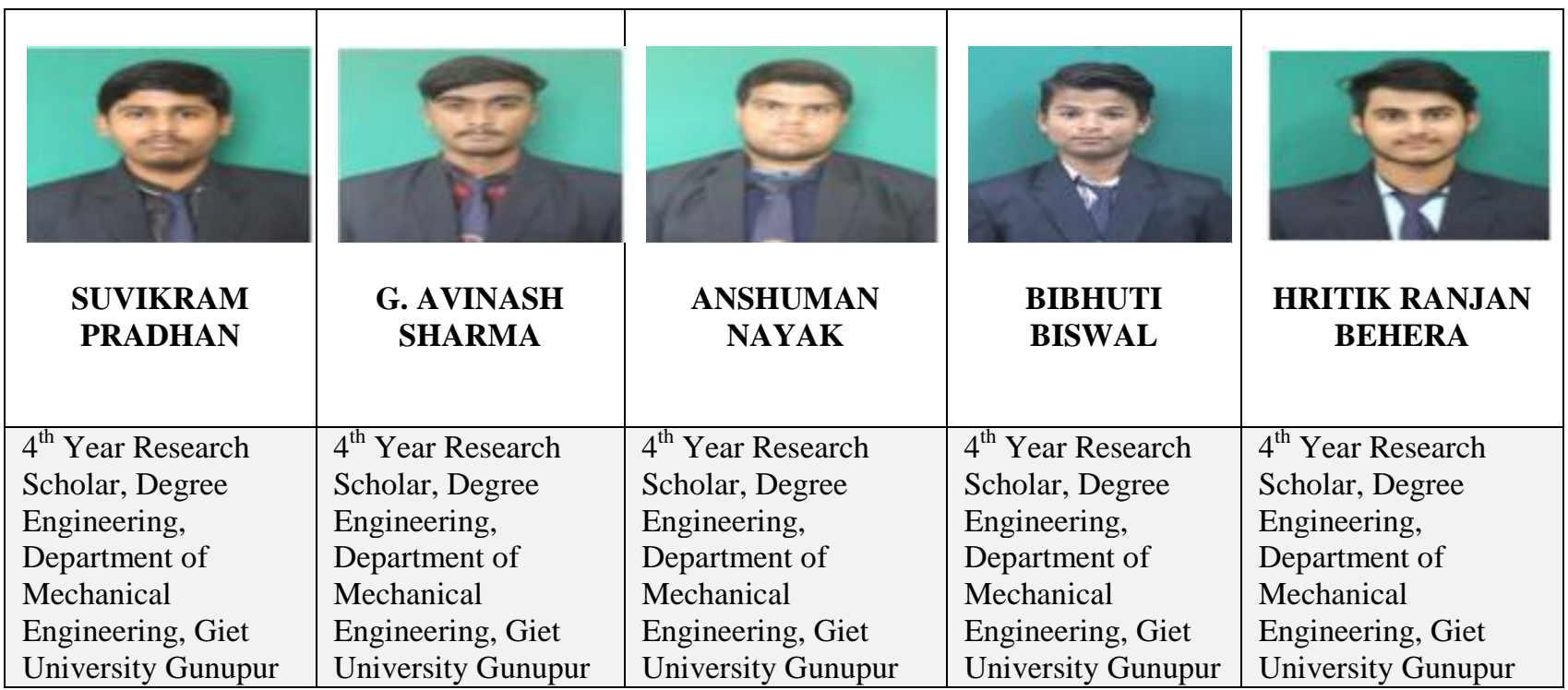

